\title{
Structural Characteristics that Influence on the Insecticidal Activity of 2-(n-Octyl)pseudothiourea Analogues against the Diamondback Moth (Plutella xylostella, L.)
}

\author{
Min-Gyu Soung, Mun-Jae Kil, and Nack-Do Sung- \\ Department of Applied Biologv and Chemistry College of Agriculture and Life Science, Chungnam National Lniversity, \\ Daejeon 305-76t, Korea. "E-mail: ndsung15 Ghanmail.net \\ Received August 5, 2009. Accepted October 5. 2009
}

\begin{abstract}
Structural characteristics that influence on the insecticidal activity $\left(\mathrm{pI} \mathrm{I}_{0}\right)$ of 2 -(n-octy 1$)$ isothiourea analogues $(\mathbf{1 - 4 5})$ against the diamondback moth (Plitellaxylostella $\mathrm{L}$.) based on three dimensional quantitative structure activity relationships (3D-QSARs) were discussed quantitatively using a comparative molecular field analy sis (CoMFA) and a comparative molecular similarity indeces analy sis (CoMSIA) methods. The statistical values of the CoMFA 2 model were better than those of the CoMSLA I model. The CoMFA 2 model was the optimized model with the correlativity (the training set: Ave $=0.104$ \&RESS $=0.613$ ) and the predictability (the test set: Ave $=0.086 \&$ PRESS $=0.096$ ). Insecticidal activities with the optinized CoMFA 2 model were dependent upon steric factors $(79.4 \%)$ of $\mathrm{R}_{1}-\mathrm{R}_{3}$ substituents. From the analy tical results of CoMFA contour maps, it is predicted that the $\mathrm{R}_{1}$ substituent of 1-45 which has a steric favor in a broad space, $R_{2}$ and $R_{3}$ groups with a steric favor in a narrow space and a $H$-bond donor favor would have better the insecticidal activity.
\end{abstract}

Key Words: 2-(n-Octyl)isothiourea analogues, Diamond back moth (Plutella xvlostella, Linnaets). Insecticidal activity. CoMFA. CoMSIA

\section{Introduction}

Because of the active use of organic sy nthesized insecticides in various pest controls. there has been a continual increase in diverse resistance pests. And. it was reported recently that the number has reached +30 different species. ${ }^{1 . *}$ The stidies to develop insecticides with an induced selectivity, as well as the efforts to control the ovenuse or the misuse of insecticides. are lively progressing in order to reduce resistance. ${ }^{3}$ As a solution to the given problems. there has been much attention toward the unique insecticidal activity caused by the perturbance ${ }^{+}$in the path where the chitin. a monomer whose main component is the $\mathrm{N}$-acetylglucosamine existing in the cuticles and found only within insects. is composited and stored. As a result of such interest in the insecticidal activity. approximately 20 different types of urea-class insecticides. including Diflubenzuron. Teflubenzuron, Triflumuron and Hexaflumuron. have been developed. ${ }^{5}$

The diamondback moth (Plutella xylostella. L.) which is one of the targeted pests of insecticides. has caused much damage to cruciferae vegetables that include a cabbage (Brassica campestris), a radish (Raphants sativis). and a kale (Brassica olera$c e a)$. There are currently 23 different types of chemicals registered for use in the Korea Crop Protection Association including organophosphates, carbamates, synthetic py rethroids insect growth regulators. and BT (Bacillis thuringiereic). dnigs to prevent damages from the diamondback moths. ${ }^{6}$ Among these. the buprofezin (conmercial nume is Applauda) was developed to control insect pests. The selective insecticidal activity toward the 1-(n-propyl)-2-(n-octyl)-3-isopropylisothiourea molecule, which is a partial modification of the buprofezin molecule's 2amino-1,3.5-thiadiazin-t-one ring, has been confirmed to be effective for a diamondback moth as opposed to a brown plant hopper (Nilaparvata lugens). ${ }^{8}$ However there have not been many studies on the improvement or the selective insecticidal activities of isothiourea analogues and the buprofezin.?

So far lepidoptericides to western spruce budworm ${ }^{10}$ structure activity relationship on the insecticidal activity of the larvae of cotton leafwonn (Spodoptera ittoralis) and mosquito (Cutex pipiens) ${ }^{11}$ effect on pupation and intago emergence of housefly larvae. ${ }^{1 .}$ activity as phy totoxic and fungicidal agent, ${ }^{13}$ miticidal activity. ${ }^{14}$ nematocidal activity ${ }^{15}$ and use for the control of pests ${ }^{16}$ by isothiourea analogues were evaluated and studied. Recently. the authors have reported on the physicochemical properties and characteristics of substituents in the isothiourea analogues that contribute to the insecticidal activities using the two dimensional quantitative stnucture activity relationship (2D-QSAR) $)^{8.15}$ and hologram quantitative structure activity relationship (HQSAR) analy'sis on the insecticidal activities of 2-(n-octyl)isothiourea analogues against a diamondback moth. ${ }^{18}$

In order to search for new insecticidal compounds. we caried out three dimensional quantitative structure activity relationships (3D-QSARs) analyses (CoMFA: comparative molecular field analysis \& CoMSIA: conmparative molecular sinularity indeces analysis $)^{19}$ between the structures of the $2-(n-0 \mathrm{cty})$ isothiourea analogues and their insecticidal activities $(O b s$. $\left.\mathrm{pI}_{5(0)}\right)^{3,17.18}$ against the diamondback moth. Furthermore. we reviewed the structural characteristics of highly activated molecules in this study.

\section{Matevials and Methods}

3D-QSAR/PLS analyses. The author's resources were used for the insecticidal activity $\left(O b s . p I_{5_{0}}\right.$ ) against the diamondback moth (Plitellaxvlostella, L.) due to the changes of substituents 
$\left(\mathrm{R}_{\mathrm{J}} \sim \mathrm{R}_{3}\right)$ among the $2-(n-0 \mathrm{cty})$ isothiourea analogues. namely, $1-\left(R_{1}\right)-2-(X)-3,3-\left(R_{2} . R_{3}\right)$ isothiourea (hereinafter referred to as the Urea: Fig. 1). ${ }^{18}$ Overall. each of the CoMFA and CoMSIA models was performed according to the conditions and methods of the previous reports ${ }^{2 i}$ with the Sỵbyl (Ver. 8.1) program (Tripos Inc., St. Louis, MO). CoMFA was carried out to evaluate the steric and electrostatic. and hýdrophobic properties as additional

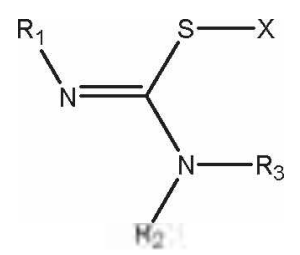

Figure 1. General structure of $1-\left(\mathrm{R}_{1}\right)-2-(\mathrm{X})-\hat{3}, 3-\left(\mathrm{R}_{2}, \mathrm{R}_{3}\right.$ pseudothiourea analogues $(\mathrm{X}=n$-octy $\mathrm{l}$ ) against the diamond back moth (Plufella $x$ losfella, L). descriptor. And also, CoMSIA carried out to evaluate the steric, electrostatic. lydrophobic. $\mathrm{H}$-bond donor and $\mathrm{H}$-bond acceptor properties associated with the activities of the Urea analogues. Among the overall 45 data set compounds, 36 compounds of them were a training set $(n=36)$ used to perfonm of 3D-QSARs models. For the predictability of each of the models was evaluated the remaining 9 compounds were used as a test set $(n=9)$. The study searched for the most stable three dimensional conformer then by the simulated amealing method. ${ }^{21}$ And, the two alignments ( $\mathrm{AF}$ : atom based fit \& FF: field fit) based on the Urea $\left(\mathrm{R}_{1}=\mathrm{R}_{2}=\mathrm{R}_{3}=\mathrm{H}\right)$ molecular template were used to align each compound in the three dimensional space. Then, the relationships between the descriptor of the structural characteristics of aligned compounds and insecticidal activities ( $O b s . \mathrm{pl} \mathrm{s}_{\text {si. }}$ ) were analyzed by a partial least square (PLS) method. ${ }^{\text {to }}$ From the cross-validation process. we investigated the leave-one-out (LOO) predictability ( $\mathrm{q}^{2}$ or $\mathrm{r}_{\mathrm{cv}}^{2}$ ) and the mumber of components.

Table 1. Observed insecticidal activity (Obs.pIso) of the Ureas against the diamond back moth and predicted activity (Pred.pIso) by the 3D-QSAR models for the training set

\begin{tabular}{|c|c|c|c|c|c|c|c|c|}
\hline \multirow{2}{*}{ No. } & \multicolumn{3}{|c|}{ Substituents (R) } & \multirow{2}{*}{$\begin{array}{l}\text { Obs. } \\
\mathrm{pI}_{50}\end{array}$} & \multicolumn{2}{|c|}{ COMFA 2} & \multicolumn{2}{|c|}{ COMSIA I } \\
\hline & 1 & 2 & 3 & & Pred $^{a}$ & $4 p l w^{\prime}$ & Pred $^{2}$ & $\Delta p m_{m}^{\prime \prime}$ \\
\hline 1 & $\mathrm{C}_{n} \mathrm{H}_{2} \mathrm{C}=\mathrm{O}$ & $\mathrm{CH}\left(\mathrm{CH}_{3}\right)_{2}$ & $\mathrm{CH}\left(\mathrm{CH}_{3}\right)=$ & 3.40 & 3.63 & -0.23 & 3.44 & -0.04 \\
\hline 2 & $4-\mathrm{CIC}_{6} \mathrm{H}_{4} \mathrm{CH}_{2}$ & $\mathrm{CH}\left(\mathrm{CH}_{3}\right)_{2}$ & $\left.\mathrm{CH}_{(\mathrm{CH}}\right)$ & 3.45 & 3.20 & 0.25 & 3.35 & 0.10 \\
\hline 3 & $4-\mathrm{FC}_{n} \mathrm{H}_{4}$ & $\mathrm{CH}\left(\mathrm{CH}_{3}\right)_{2}$ & $\left.\mathrm{CH}_{(\mathrm{CH}}\right)=$ & 2.94 & 2.85 & 0.09 & 3.05 & -0.11 \\
\hline 4 & $4-\mathrm{CIC}_{6} \mathrm{H}_{4}$ & $\mathrm{CH}\left(\mathrm{CH}_{3}\right)_{2}$ & $\mathrm{CH}\left(\mathrm{CH}_{3}\right)$ & 3.09 & 2.90 & 0.19 & 3.60 & 0.09 \\
\hline 6 & $4-\mathrm{BrC}_{6} \mathrm{H}_{4}$ & $\mathrm{CH}\left(\mathrm{CH}_{3}\right)_{2}$ & $\mathrm{CH}\left(\mathrm{CH}_{3}\right)_{2}$ & 2.83 & 2.93 & -0.10 & 2.92 & -0.09 \\
\hline 7 & $4-\mathrm{CH}_{3} \mathrm{OC}_{6} \mathrm{H}_{4}$ & $\mathrm{CH}\left(\mathrm{CH}_{3}\right)_{2}$ & $\mathrm{CH}\left(\mathrm{CH}_{3}\right)_{2}$ & 3.08 & 2.94 & 0.14 & 2.88 & 0.20 \\
\hline 9 & $3-\mathrm{CH}_{3} \mathrm{OC}_{6} \mathrm{H}_{4}$ & $\mathrm{CH}\left(\mathrm{CH}_{3}\right)_{2}$ & $\mathrm{CH}\left(\mathrm{CH}_{3}\right)_{2}$ & 3.33 & 3.36 & -0.03 & 3.35 & -0.02 \\
\hline 10 & $3-\mathrm{CNC}_{5} \mathrm{H}_{4}$ & $\mathrm{CH}\left(\mathrm{CH}_{3}\right)_{2}$ & $\mathrm{CH}\left(\mathrm{CH}_{2}\right)_{2}$ & 3.17 & 3.22 & -0.05 & 3.36 & -0.19 \\
\hline 12 & $\mathrm{CH}_{3}$ & $\mathrm{CH}\left(\mathrm{CH}_{3}\right)_{2}$ & $\mathrm{CH}\left(\mathrm{CH}_{3}\right)_{2}$ & 2.77 & 3.00 & -0.23 & 3.09 & -0.32 \\
\hline 13 & $\mathrm{C}_{2} \mathrm{H}_{5}$ & $\mathrm{CH}\left(\mathrm{CH}_{3}\right)_{2}$ & $\mathrm{CH}\left(\mathrm{CH}_{3}\right)_{2}$ & 3.30 & 3.48 & -0.18 & 3.32 & -0.02 \\
\hline 14 & $n-\mathrm{C}_{2} \mathrm{H}=$ & $\mathrm{CH}\left(\mathrm{CH}_{3}\right)_{2}$ & $\mathrm{CH}\left(\mathrm{CH}_{3}\right)_{2}$ & 3.90 & 3.68 & 0.22 & 3.53 & 0.37 \\
\hline 15 & $\mathrm{CH}_{2} \mathrm{CH}=\mathrm{CH}_{2}$ & $\mathrm{CH}\left(\mathrm{CH}_{3}\right)_{2}$ & $\mathrm{CH}\left(\mathrm{CH}_{3}\right)_{2}$ & 3.72 & 3.72 & 0.00 & 3.66 & 0.06 \\
\hline 17 & $n-\mathrm{C}_{+} \mathrm{H}_{9}$ & $\mathrm{CH}\left(\mathrm{CH}_{3}\right)_{2}$ & $\mathrm{CH}\left(\mathrm{CH}_{3}\right)_{2}$ & 4.00 & 3.83 & 0.17 & 3.84 & 0.16 \\
\hline 18 & $\mathrm{C}_{2} \mathrm{H}_{4} \mathrm{CH}\left(\mathrm{CH}_{3}\right)_{2}$ & $\mathrm{CH}\left(\mathrm{CH}_{3}\right)_{2}$ & $\mathrm{CH}\left(\mathrm{CH}_{3}\right)_{2}$ & 3.80 & 3.86 & -0.06 & 3.93 & -0.13 \\
\hline 19 & $n-\mathrm{C}_{5} \mathrm{H}_{11}$ & $\mathrm{CH}\left(\mathrm{CH}_{3}\right)_{2}$ & $\mathrm{CH}\left(\mathrm{CH}_{3}\right)_{2}$ & 3.83 & 3.83 & 0,00 & 3.89 & -0.06 \\
\hline 20 & $\mathrm{C}_{2} \mathrm{H}_{+} \mathrm{OC}_{3} \mathrm{H}_{-}$ & $\mathrm{CH}\left(\mathrm{CH}_{3}\right)_{2}$ & $\mathrm{CH}\left(\mathrm{CH}_{2}\right)_{2}$ & 3.80 & 3.85 & -0.05 & 3.65 & 0.15 \\
\hline 22 & $\mathrm{Cy}-\mathrm{C}_{n} \mathrm{H}_{\mathrm{ll}}$ & $\mathrm{CH}\left(\mathrm{CH}_{3}\right)_{2}$ & $\mathrm{CH}\left(\mathrm{CH}_{3}\right)=$ & 3.75 & 3.56 & 0.19 & 3.56 & 0.19 \\
\hline $2 \hat{3}$ & $\mathrm{Cy}-\mathrm{C}_{n} \mathrm{H}_{11} \mathrm{CH}_{2}$ & $\mathrm{CH}\left(\mathrm{CH}_{3}\right)_{2}$ & $\mathrm{CH}\left(\mathrm{CH}_{3}\right)=$ & 3.30 & 3.42 & -0.12 & 3.51 & -0.21 \\
\hline 24 & $\mathrm{Cy}-\mathrm{C} \cdot \mathrm{H}_{15}$ & $\mathrm{CH}\left(\mathrm{CH}_{3}\right)_{2}$ & $\mathrm{CH}\left(\mathrm{CH}_{3}\right)=$ & 3.32 & 3.50 & -0.18 & 3.53 & -0.21 \\
\hline 25 & $n-\mathrm{C}_{6} \mathrm{H}_{13}$ & $\mathrm{CH}\left(\mathrm{CH}_{3}\right)_{2}$ & $\mathrm{CH}\left(\mathrm{CH}_{3}\right)=$ & 3.80 & 3.82 & -0.02 & 3.63 & 0.17 \\
\hline 27 & ${ }^{n}-\mathrm{C}_{3} \mathrm{H}$ & $\mathrm{H}$ & $\mathrm{Me}$ & 2.63 & 2.72 & -0.09 & 2.69 & -0.06 \\
\hline 28 & $n-\mathrm{C}_{\$} \mathrm{H}$ & $\mathrm{H}$ & $\mathrm{C}_{\hat{\Delta}} \mathrm{H}_{s}$ & 2.83 & 2.85 & -0.02 & 2.76 & 0.07 \\
\hline 29 & $n-C_{\$} \mathrm{H}_{2}$ & $\mathrm{H}$ & $\mathrm{CH}=\mathrm{CH}_{2}$ & 2.86 & 2.70 & 0.16 & 2.92 & -0.06 \\
\hline 30 & $n-C_{3} \mathrm{H}_{2}$ & $\mathrm{H}$ & $\mathrm{CH}\left(\mathrm{CH}_{3}\right)=$ & 300 & 2.82 & 0.18 & 2.90 & 0.10 \\
\hline 31 & $n-\mathrm{C}_{\$} \mathrm{H}$ & $\mathrm{H}$ & $\mathrm{Cy}-\mathrm{C}_{3} \mathrm{H}_{3}$ & 2.85 & 2.78 & 0.07 & 2.86 & -0.01 \\
\hline 32 & $n-\mathrm{C}_{3} \mathrm{H}$ & $\mathrm{H}$ & $\mathrm{CH}\left(\mathrm{CH}_{3}\right) \mathrm{C}_{2} \mathrm{H}_{3}$ & 2.88 & 2.89 & -0.01 & 2.97 & -0.09 \\
\hline 34 & $n-C_{\$} \mathrm{H}_{2}$ & $\mathrm{H}$ & $\mathrm{CH}\left(\mathrm{C}_{2} \mathrm{H}_{3}\right) \mathrm{C}_{2} \mathrm{H}_{3}$ & 2.89 & 2.92 & -0.03 & 2.98 & -0.09 \\
\hline 36 & $n-C_{s} \mathrm{H}$ & $\mathrm{H}$ & $\mathrm{C}\left(\mathrm{CH}_{3}\right)_{5}$ & 2.88 & 2.91 & -0.03 & 3.06 & -0.18 \\
\hline 37 & $n-\mathrm{C}_{3} \mathrm{H}=$ & $\mathrm{H}$ & $\mathrm{Cy}-\mathrm{C}_{4} \mathrm{H}_{7}$ & 2.89 & 2.90 & -0.01 & 2.88 & 0.01 \\
\hline 38 & ${ }_{n}-\mathrm{C}_{3} \mathrm{H}=$ & $\mathrm{H}$ & $\mathrm{CH}_{2} \mathrm{CH}\left(\mathrm{CH}_{3}\right)_{2}$ & 2.90 & 2.87 & 0.03 & 2.76 & 0.14 \\
\hline 39 & ${ }_{n}-\mathrm{C}_{3} \mathrm{H}=$ & $\mathrm{H}$ & ${ }_{n-\mathrm{C}_{5} \mathrm{H}_{11}}$ & 2.73 & 2.79 & -0.06 & 2.78 & -0.05 \\
\hline 40 & $n-\mathrm{C}_{2} \mathrm{H}=$ & $\mathrm{H}$ & $\mathrm{C} y-\mathrm{C}_{5} \mathrm{H}_{0}$ & 2.90 & 2.95 & -0.05 & 2.91 & -0.01 \\
\hline 42 & ${ }_{n}-\mathrm{C}_{3} \mathrm{H}=$ & $\mathrm{H}$ & ${ }_{77-\mathrm{C}_{6}} \mathrm{H}_{13}$ & 2.44 & 2.33 & 0.11 & 2.20 & 0.24 \\
\hline 43 & $n-\mathrm{C}_{3} \mathrm{H}=$ & $\mathrm{H}$ & $\mathrm{Cy}_{y}-\mathrm{C}_{6} \mathrm{H}_{\mathrm{ll}}$ & 2.90 & 2.96 & -0.06 & 2.99 & -0.09 \\
\hline 44 & $n-\mathrm{C}_{3} \mathrm{H}=$ & $\mathrm{H}$ & ${ }_{n-C}-\mathrm{C}_{-} \mathrm{H}_{15}$ & 2.11 & 2.04 & 0.07 & 1.97 & 0.14 \\
\hline 45 & ${ }_{n}-\mathrm{C}_{2} \mathrm{H}_{2}$ & $\mathrm{H}$ & ${ }_{n}-\mathrm{C}_{8} \mathrm{H}_{1}$ & 1.62 & 1.88 & -0.26 & 1.80 & -0.18 \\
\hline
\end{tabular}

Note: $\mathrm{Cy}$, crelo form. "the optimized model; "predicted values by the 3D-QSAR models: differences between the observed value and the predicted value. 
Table 2. Summary of the statistical parameters of 3D-QSAR models with two alignments

\begin{tabular}{|c|c|c|c|c|c|c|c|c|}
\hline \multirow{2}{*}{ Model No. } & \multirow{2}{*}{ Alignments } & \multirow{2}{*}{$\alpha^{\sigma}$} & \multicolumn{6}{|c|}{ PLS Analyses } \\
\hline & & & Grid $(A)$ & $\mathrm{NC}$ & $\mathrm{r}^{2} \mathrm{v}^{b}$ & $r_{\text {tuv. }}^{2}$ & $S E_{\mathrm{kn}}{ }^{d}$ & $\mathrm{~F}$ \\
\hline COMFA 1 & $\mathrm{AF}$ & - & 1.0 & 5 & 0.554 & 0.901 & 0.175 & 54.867 \\
\hline $\operatorname{CoMFA} 2^{\circ}$ & $\mathrm{FF}$ & - & 1.0 & 5 & 0.554 & 0.935 & 0.143 & 85.785 \\
\hline COMSIA 1 & $\mathrm{AF}$ & 0.3 & 2.5 & 5 & 0.629 & 0.915 & 0.163 & 64.63 \\
\hline COMSIA 2 & $\mathrm{FF}$ & 0.3 & 1.0 & 5 & 0.701 & 0.912 & 0.165 & 62.211 \\
\hline
\end{tabular}

Notes: Alignments: AF: atom based fitt: FF: field fit: NC: number of component: F: fraction of explained versus unexplained variance: ${ }^{a}$ attenuation tactor (a): "cross-validated r"; "non-cross-Falıdated r"; "standard error estimate; "optimized model.

Table 3. Observed insecticidal activity (Obs.p $\mathrm{I}_{s_{1}}$ ) of the Ureas against the diamond back moth and predicted activity (Pred.pI $\mathrm{s}_{0}$ ) by the 3D-QSAR model for the test set

\begin{tabular}{|c|c|c|c|c|c|c|c|c|}
\hline \multirow{2}{*}{ No. } & \multicolumn{3}{|c|}{ Substituents (R) } & \multirow{2}{*}{$\begin{array}{l}\text { Obs. } \\
\text { pIs0 }\end{array}$} & \multicolumn{2}{|c|}{ CoMFA 2} & \multicolumn{2}{|c|}{ CoMSIA 1} \\
\hline & 1 & 2 & 3 & & Pred" & $\Delta \mathrm{pI}_{S \mathbb{Q}^{\prime \prime}}$ & Pred $^{\prime \prime}$ & $\Delta \mathrm{pI}_{s\left(\mathrm{l}^{\prime \prime}\right.}$ \\
\hline 5 & $4-\mathrm{NO}_{2} \mathrm{C}_{6} \mathrm{H}_{4}$ & $\mathrm{CH}\left(\mathrm{CH}_{3}\right)_{2}$ & $\mathrm{CH}\left(\mathrm{CH}_{2}\right)_{2}$ & 2.97 & 2.88 & 0.09 & 2.98 & -0.01 \\
\hline 8 & $3-\mathrm{BrC}_{6} \mathrm{H}_{4}$ & $\mathrm{CH}\left(\mathrm{CH}_{3}\right)_{2}$ & $\mathrm{CH}\left(\mathrm{CH}_{2}\right)_{2}$ & 3.23 & 3.20 & 0.03 & 3.22 & 0.01 \\
\hline 11 & $3-\mathrm{NO}_{2} \mathrm{C}_{6} \mathrm{H}_{4}$ & $\mathrm{CH}\left(\mathrm{CH}_{3}\right)_{2}$ & $\mathrm{CH}\left(\mathrm{CH}_{2}\right)_{2}$ & 3.34 & 3.16 & 0.18 & 3.00 & 0.34 \\
\hline 16 & $\mathrm{CH}_{2} \mathrm{CH}\left(\mathrm{CH}_{3}\right)_{2}$ & $\mathrm{CH}\left(\mathrm{CH}_{3}\right)_{2}$ & $\mathrm{CH}\left(\mathrm{CH}_{2}\right)_{2}$ & 3.89 & 3.80 & 0.09 & 3.86 & 0.03 \\
\hline 21 & $\mathrm{Cy}-\mathrm{C}_{s} \mathrm{H}_{9}$ & $\mathrm{CH}\left(\mathrm{CH}_{3}\right)_{2}$ & $\mathrm{CH}\left(\mathrm{CH}_{3}\right)_{2}$ & 3.78 & 3.62 & 0.16 & 3.68 & 0.10 \\
\hline 26 & $n-\mathrm{C}_{3} \mathrm{H}$ & $\mathrm{H}$ & $\mathrm{H}$ & 2.38 & 2.39 & -0.01 & 2.37 & 0.01 \\
\hline $3 \hat{3}$ & ${ }^{n-C_{3}} \mathrm{H}_{-}$ & $\mathrm{H}$ & $\mathrm{C}\left(\mathrm{CH}_{3}\right)_{2} \mathrm{C}_{2} \mathrm{H}_{s}$ & 2.90 & 3.02 & -0.12 & 3.12 & -0.22 \\
\hline 35 & ${ }^{n}-\mathrm{C}_{3} \mathrm{H}_{-}$ & $\mathrm{H}$ & $n-\mathrm{C}_{4} \mathrm{H}_{10}$ & 2.82 & 2.83 & -0.01 & 3.04 & -0.22 \\
\hline 41 & ${ }^{n}-\mathrm{C}_{3} \mathrm{H}_{\bar{z}}$ & $\mathrm{H}$ & $\mathrm{C}_{2} \mathrm{H}_{4} \mathrm{CH}\left(\mathrm{CH}_{3}\right)_{2}$ & 2.86 & 2.94 & -0.08 & 2.97 & -0.11 \\
\hline
\end{tabular}

Optimized model: "predicted values by the 3D-QSAR models: 'difterences between the abserzed falue and the predicted ralue.

By using the non-cross-yalidation process, the correlativity $\left(\mathrm{r}^{-}\right.$nev $)$was examined. The predictive residual sum of the square (PRESS) value with the cross-validation. which is the sum of a squared variation between the observed value and the predicted value by the optimized model. was calculated to evaluate a predictability of model. Also. the contour maps present informations in the CoMFA and CoMSIA field of the optimized model. The rate (\%) of favor and disfavor contribution (stdev*coeff) was $80 \%$ and $20 \%$. respectively.

\section{Results and Discussion}

3D-QSAR models. The observed insecticidal activity (Obs. $\mathrm{pI}_{5(\mathrm{i})}$ against the diamondback moth by changes in the substituents $\left(\mathrm{R}_{1} \sim \mathrm{R}_{3}\right)$ of the Urea, the predicted insecticidal activity (Pred.pI ${ }_{\text {ii }}$ calculated by the optimized CoMFA2 and CoMSIA $\mathrm{I}$ models. and the difference values $\left(\Delta \mathrm{pI}_{5 \mathrm{D}}\right.$ ) between the two activities were summarized in Table 1 . The $\mathrm{R}_{1}=n$-butyl, $\mathrm{R}_{2}=$ $\mathrm{R}_{3}=$ iso-propyl substituent (17) showed the strongest insecticidal activity $\left(O b s \cdot \mathrm{pI}_{5}=4.00\right)$. while that of the $\mathrm{R}_{\mathrm{l}}=n$-propyl. $\mathrm{R}_{2}=\mathrm{H}, \mathrm{R}_{3}=n$-octyl substitient $(\mathbf{4 5})$ was the weakest $\left(O b s . \mathrm{p} \mathrm{I}_{\mathrm{s}}=\right.$ 1.62). and their difference in activity values was $\triangle O b s: \mathrm{pI}_{5(1}=$ 2.38. Both of the CoMFA and CoMSIA models were performed by changes in the alignments ( $\mathrm{AF}$ : atom based fit $\& \mathrm{FF}$ : field fit). a grid space $(1.5-3.0 \mathrm{~A})$ and component numbers $(2-7)$. The COMFA model was induced by the combination forms of 3 CoMFA fields such as the indicator field. the standard field and the H-bond field. For the CoMSIA model. it was induced by the combination fonms of 5 CoMSIA fields include the steric field, the electrostatic field, the hydrophobic field. the H-bond donor field and the $\mathrm{H}$-bond acceptor field. respectively. Table
2 shows statistical results of the COMFA and COMSIA models based on the 2 alignments. The four 3D-QSAR models showed high correlativity $\left(r^{2}\right.$ nce $)$ in the order of COMFA $2>$ COMSIA 1 model $\geq$ CoMSIA 2 model $>$ CoMFA 1 model. The optimized model with the most favorable statistical value was the CoMFA 2 model (predictability: $\mathrm{r}^{2}=0.554 \&$ correlativity: $\mathrm{r}_{\mathrm{ncu}}^{2}=$ 0.935 ) induced in the FF alignment condition. The CoMSIA models showed sinular statistical values regardless of the two different alignment conditions. but the CoMSIA I model showed more favorable values compared to the CoMSIA 2 model.

Predictability of optimized modkl. The observed insecticidal activity (Obs $\mathrm{pI} \mathrm{I}_{\mathrm{s}}$ ) of the test set compounds. the predicted insecticidal activity (Pred.pI 5 ) by the COMFA 2 model and CoMSIA 1 model, and the difference $\left(\Delta \mathrm{pI}_{51}\right)$ of the two values were summarized in Table 3. In order to validate the predictability of models. the averages (Ave.) and the PRESS values of each model were calculated and summarized in Table 4. The most statistically reliable model was the CoMFA 2 model. In addition. it could be confirmed that the CoMFA 2 model was the optinized model with the following: the correlativity (the training set: Ave. $=0.104$ and PRESS $=0.613$ ) and the predictability (the test set: Ave $=0.086$ and PRESS $=0.096$ ).

Figure 2 shows the correlation (the training set: Pred.pI $\mathrm{pI}_{\mathrm{s},}=$ $0.93+$ Obs. $\mathrm{pI}_{5 \mathrm{c}}+0.202, \mathrm{n}=36 . \mathrm{s}=0.130, \mathrm{~F}=479.838, \mathrm{r}^{2}=$ $0.934 \& \mathrm{q}^{2}=0.920$ ) between the observed insecticidal activity (Obs. $\left.\mathrm{pI}_{501}\right)$ and the predicted value (Pred.pI $\mathrm{I}_{51}$ ) obtained from the CoMFA 2 model. Its liner correlation explains that the cornelativity of CoMFA 2 model is the highest. The contribution ratio $(\%)$ of the CoMFA field due to the optimized CoMFA 2 model showed $79.4 \%$ for the steric field, $16.8 \%$ for the electrostatic field and $3.8 \%$ for the hydrophobic field. Thus 
Table 4. Summary of Ave.. PRESS and field contribution of 3D-QSAR models

\begin{tabular}{lccccccccc}
\hline \multirow{2}{*}{ Model No. } & \multicolumn{2}{c}{ Training set" } & \multicolumn{2}{c}{ Test set } & \multicolumn{4}{c}{ l'ield contribution ratio (\%) } \\
& Ave. & PRESS & Ave. & PRESS & S & E & Hy & HD & HA \\
\hline CoMFA 1 & 0.119 & 0.915 & 0.099 & 0.129 & 67.6 & 30.3 & 2.0 & - & - \\
CoMHA 2 & 0.104 & 0.613 & 0.086 & 0.096 & 79.4 & 16.8 & 3.8 & - & - \\
CoMSIA 1 & 0.123 & 0.792 & 0.117 & 0.236 & 22.8 & 21.2 & 36.6 & 19.4 & - \\
COMSLA 2 & 0.115 & 0.824 & 0.179 & 0.588 & - & - & 61.2 & 32.3 & 6.5 \\
\hline
\end{tabular}

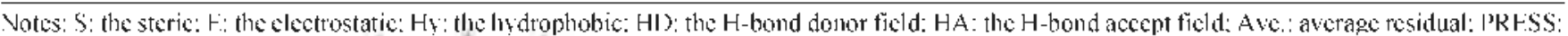
predictive residual sum of squates: $" n=36$ : $\mathrm{n}=9$ : the optimized model.

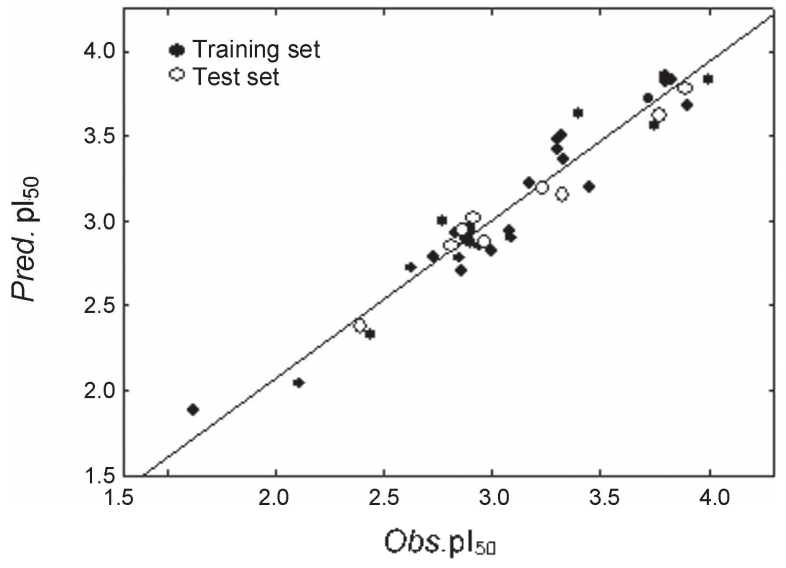

Figure 2. Relationships between observed insecticidal activities $(O b)$.

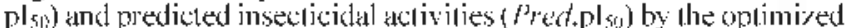

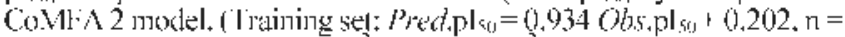
36. $s=0.130 . \mathrm{F}=479.838 \cdot \mathrm{r}^{2}=0.934 \& \mathrm{q}^{2}=0.920$ ).

the steric field shows the highest contribution ratios of two CoMFA models. This means that the steric field is the most important factor. Still, the Hydrophobic field ( $\mathrm{Hy}$ ) in CoMSlA fields had simultaneously the largest effects, and specifically the $\mathrm{H}$-bond donor field $(\mathrm{HD}=19.4 \% \sim 32.3 \%$ ) showed a comparatively large contribution ratio.

Analyses of contourmaps. The contour maps obtained from the optimized CoMFA 2 model were shown in the capped sticks of the $\mathrm{R}_{1}=n$-butyl, $\mathrm{R}_{2}=\mathrm{R}_{3}=i$ iso-propyl substituent (17) which is the most active compound (Obs.pl $\mathrm{l}_{50}-4.00$ ). Thus, the contour map due to the steric field is shown in Fig. 3 and the contour map due to the electrostatic and hydrophobic fields in Fig. 4. According to the Fig. 3 , in the case of the steric field ( $\mathrm{S}: 79.4 \%$ ) that had the highest contribution ratio of the insecticidal activity n the outside of $R_{1}$ and $R_{2}$-substituent are sterically small but inner side of the $\mathrm{R}_{\mathrm{l}}$-substituent is sterically large. Therefore, a sterically large substituent (steric favor) is the factor that causes an increase in the insecticidal activity. To have a strong insecticidal activity, $R_{2}$ and $R_{3}$-substituents need to be positioned near the nitrogen atom of amino group whose characteristic is sterically large. One of the reasons that the $\mathrm{R}_{1}=n$-butyl substituent (17) shows the largest insecticidal activity could be because of the fact that the $R_{1}$-substituent is sterically large.

On the other hand, the $\mathrm{R}_{1}$-substituent prefers a positive charge in the two areas from the hydropathic interaction (HINT) map ${ }^{23}$ of the hydrophobic field and the electrostatic contour map (Fig. 4). If a substituent favoring a negative charge is inserted between them, it is predicted that this would influence on the insecticidal

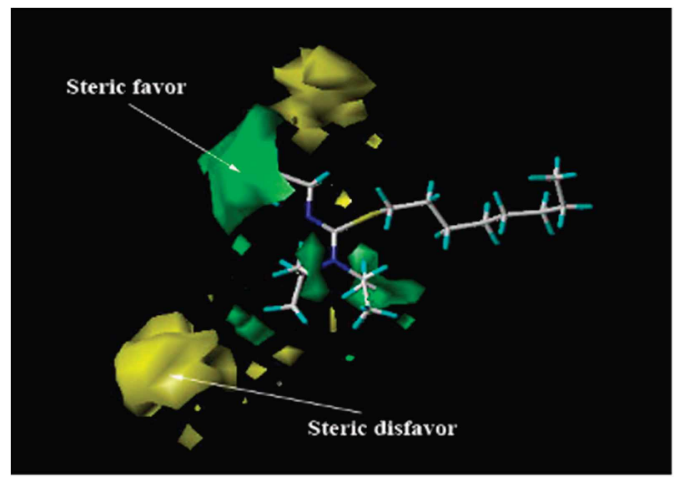

lingure 3. Contour map for the steric field with the optimized CoMl $A$ 2 model. The most active compound (17) is show $n$ in capped sticks (favor: $80 \%$. distavor: $20 \%$ ).

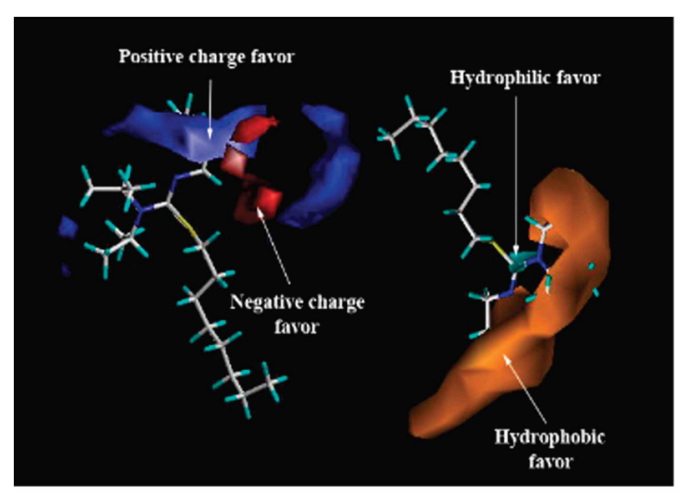

Figure 4. Contour maps for an electrostatic ticld and a hydrophobic ficld (COMFA-HINT) with the optimized CoMFA 2 model (stdev* coetl). The most active compound (17) is shown in capped sticks (Iavor: $80 \%$. dislavor: $20 \%$ ).

activity. Although the contour maps of the CoMSIA models were not showed, the hydrophobic field ( $\mathrm{Hy}: 36.6 \%-61.2 \%$ ) alone prefers hydrophobicity at the region of $\mathrm{R}_{1}$ and $\mathrm{R}_{2}$-substituent as the HINT map.

Character of the most active compounds. As reviewed above, the contribution ratio $(79.4 \%)$ of the steric field was 4.7 times bigger than that of the electrostatic field $(16.8 \%)$ from the CoMFA 2 model. Compared to this, the hydrophobic field contribution ratio $(3.8 \%)$ was very sinall. Thus, expected characteristics of the substituents $\left(\mathrm{R}_{1} \sim \mathrm{R}_{3}\right)$ to influence on the insecticidal activity are as follows. That is, a sterically bulky iso-butyl or a $t$-butyl group is ideal for the $\mathrm{R}_{\mathrm{1}}$-substituent. It is predicted that the size of the $R_{2}$ and $R_{3}$-substituent should be smaller than that of the $R_{\mathrm{J}}$-substituent. The functional groups 
of them should be the H-bond donor groups such as hydronyl. amino, and imino groups. ${ }^{2+}$ It is predicted that these substituents would enhance the insecticidal activity due to a hydrogen bonding $\left(-\triangle \mathrm{H}^{\circ}=8 \sim 29 \mathrm{~kJ} / \mathrm{mol} \& \text { length }=2.70 \sim 3.10 \mathrm{~A}\right)^{-5}$ interaction with the receptors. From the 2D-QSAR analysis study, the optimal values for the descriptors of the $R_{2}$ and $\mathrm{R}_{3}$-substituents in the Urea molecules were a length ( $\left.\left(\mathrm{L}_{1}\right)_{\text {ept }}\right)$ of $5.22 \AA$ a molar refractivity ((MR) opt. $)$ of $5.70 \mathrm{~cm} / \mathrm{mol}$ and a hydrophobicity value of $\left((\pi)_{\text {spt }}\right)$ of 1.60$)$. respectively. ${ }^{8}$ It was estimated that the $M R$ value $\left((M R)_{\text {opt. }}\right)$ of the $R_{1}$-substituent should be $23.3 \mathrm{~cm}^{3} / \mathrm{mol}$. while the polarizability value $\left((\mathrm{Pol})_{\text {(xyt }}\right)$ was $43.47 \mathrm{~cm}^{3} 1^{7}$ ?

Furthermore, it was predicted from the study on the optimized HQSAR model $\left(\mathrm{r}_{\mathrm{t}}^{2}=0.918 \& \mathrm{r}_{C \cdot}^{2} \cdot\left(\right.\right.$ or $\left.\left.\mathrm{q}^{2}\right)=0.773\right)$ that the $\mathrm{X}=$ $t$-butyl substituent $\left(\mathrm{R}_{1}=n\right.$-butyl. $\mathrm{R}_{2}=\mathrm{R}_{3}=$ iso-propyl: Pred. $\mathrm{pI}_{51}$ $\left.=5.30: \mathrm{IC}_{50}=1.40 \mathrm{ppm}\right)$ should show a higher value $\left(\Delta \mathrm{pI}_{50}=\right.$ 1.46) than that of $\mathrm{X}=$ octyl substituent $\left(\mathrm{R}_{1}=n\right.$-butyl $\mathrm{R}_{2}=\mathrm{R}_{3}=$ iso-propyl; Pred.pI $\mathrm{pl}_{5 i}=3.84$ ) based on the predicted insecticidal activity. ${ }^{j 8}$ Results of the 2D-QSAR and HQSAR analyses were generally in agreement with those of the contour maps analyses. And the results allow to understand those of the Urea molecule that can largely improve the insecticidal activity according to the position of the COMFA and CoMSIA fields, the size. and shape of the substituents in a substrate molecule. As such. it is expected that the substituents $\left(R_{1}-R_{3}\right)$ composed of the CoMFA and CoMSIA fields on the contour maps should be able to significantly reinforce the insecticidal activity of the Urea molecule against the diamondback moth.

Aclonowledgments. This work was supported by a grant (No. 2009-0062913) from the National Research Foundation (NRF) of Korea.

\section{References}

1. Isavama, S.: Saito, S : Kuroda, K : Umeda, K: Kasamatsu, K. Arch. Insec. Biochent. Phisiol. 2005, $58,226$.

2. Zateirdon, G.: Theophilidis, G. Nemrosci. Lett. 2004, 365, 205

3. Enayati, A.; Ranson, H.; Hemingway, T. H.sec. Mol Biol 2005, $1+3.3$.
4. Imai, T.; Watanabe, T.; Yui, T.; Sugivama, T. Biochemt. J. 2003, 374,755 .

5. Tomlin, C. D. S. In A Wond Compenditm: The Pesticide Mfontal., 14th ed: British Crop Production Council. 7 Onni Business Centre, Omega Park, Alton, Hampshire; GlLit 2QD., U. K., 2006.

6. wwwhoreacpa.org

7. Sung. N. D.: Yu. S. I.: Choi. K. S.: Kwon. K. S. Norean J. Pestic. Sci. 1998, 2, 46.

8. Sung, N. D.: Jeong, K. C.; Jeon, D. J.: Kim, D. W. Agri. Chem. Biotechnol. $1995,38,163$

9. James, D. G. J. Econonic Entontol 2004, 97, 900.

10. Robertson, J. C.: Look, M. P. J. Georgia Enomol. Soc. 1982, 17, 466

11. (a) El-Din, A. T. F. T.; El-Deeb, S. T.; Khalifa, M. A : Ibrahim, A. M. Hededelingen van de Faculte it Landbounetenschoppen 1977. 12. 1487: (b) Fancher. L. W.: Scher. H. B. Stauffer Chenical Co., USA, Pat. WO 80-US1 $10(19800121)$; (c) Fancher. L. W: Scher, H. B. Stauffer Chemical Co., USA, Pat. US80-185462 (19800909).

12. Kondo, S.; Maekawa, K. J. Faculty Agri. Kyitshu Lniv 1976 , 20.97 .

13. Holdsworth, E.; Everest-Todd, S. Yorkshire Tar Distillers Ltd., Pat. GB 839797, CAN 54:128571, AN 1960:128571.

14. Nagásaki. F. Suzuki. T.: Ono. I.: Yamada, T.: Takahashi. E.: Hatano, R. Nippon Soda., Ltd., Japan., Pat. TP 89-55424 (19890308).

15. Bachmann, M.: Gsell, L.: Fischer, H. P. Fr. Demande., Pat. FR 88-2075 (19880222).

16. Boeger, M.; Drabek, T.; Elrenfrennd, J. Ciba-Geigy Switz, Elr Pat. EP 88-810397 (19880613)

17. Sung, N. D.: Yu, S. J.: Jeon, D. T.; Kim, D. W. Koreon J. Pestic. Sci. 1997, 1. 1

18. Cho, Y. G.; Choi, W. Y ; Sung, N. D. I. Agri. Sci. Chthgnamt Nott Liniv. 2007, $3 \%, 171$

19. Thibaut U. In $3 D$-OSAR in Dryg Design: Theory Hethods and Applications. Applications of Con F.A and Related $3 D-O S A R$ -tpproaches: Kubinyi, H., Ed; ESCOM Science Publishers B. V.: Leiden, Netherland, $1993 ; \mathrm{p}$ 643-665.

20. (a) Kim. S. J.: Myung. P. K.: Sung. N. D. Alch. Pham Res. 2008. 31, 1540 .; (b) Soung, M. G.; Lee, Y. J.; Sung, N. D. Bull Korean Chem. Soc $2009,30,613$

21. Kerr. R. Biophus J. 1964.67. 1501

22. Cramer III, R. D. Bunce, J. D. In OS AR in Drig Design and Toxicologv (Proceedings of the 6th European $S_{\text {moisinm on }} O S-A R$ ). The DILOMAIS Methods: Initial Results from a Comparative Studv of Approaches to 3D-OS.AR. Hadzi, D.: Jenman-Blazic, B., Eds.; Elsevier: Amsterdam, 1987; p 3-12.

23. Kellog, G. E.: Abraham, D. T. J. Hol. Graphics. 1992, 10, 212.

24. Schneider, G., Baringhaus, K.-H. In Molecular Design; Concepts and Applications; Wiley-VCH: Frankfurt, Gemany, 2007; p 6465.

25. Etter, M. C. Acc. Chem. Res. 1990, 23, 120. 